\title{
Korelasi Derajat Obesitas dengan Prestasi Belajar Siswa Sekolah Dasar
}

\author{
Kadek Hartini, * Soetjiningsih, * Neti Nurani** \\ *Bagian/SMF Ilmu Kesehatan Anak Fakultas Kedokteran Universitas Udayana-RSUP Sanglah, Denpasar \\ **Bagian/SMF Ilmu Kesehatan Anak Fakultas Kedokteran Universitas Gadjah Mada-RS dr. Sardjito, \\ Yogyakarta
}

\begin{abstract}
Latar belakang. Kejadian obesitas saat ini meningkat di seluruh dunia. Semakin berat derajat obesitas, komorbid yang dialami oleh anak obesitas juga semakin banyak. Obesitas menimbulkan stigma pada masyarakat, bahwa anak obesitas adalah anak yang malas, jelek dan bodoh. Hubungan yang jelas antara obesitas dengan prestasi belajar anak di sekolah belum dapat dibuktikan.

Tujuan. Mengetahui hubungan derajat obesitas pada siswa sekolah dasar (SD) dengan prestasi belajar di sekolah.

Metode. Potong lintang analitik dan pemilihan sampel penelitian dilakukan dengan acak bertingkat. Penelitian dilakukan pada siswa sekolah dasar yang berusia 6-13 tahun di Denpasar, dari Januari 2011 sampai dengan Juni 2011.

Hasil. Penelitian dilakukan pada 1305 siswa SD yang disurvei, didapatkan $211(16,1 \%)$ anak menderita obesitas. Didapatkan $60 \%$ berjenis kelamin laki-laki dengan rentangan umur 7 sampai 12 tahun dan rentangan IQ 81 sampai dengan 119. Analisis regresi linier menunjukkan bahwa penurunan nilai rerata bahasa Indonesia $23 \%$ dan penurunan nilai rerata matematika $15 \%$ berhubungan dengan peningkatan persentase derajat obesitas.

Kesimpulan. Derajat obesitas berhubungan dengan prestasi belajar siswa sekolah dasar. Derajat obesitas ditemukan berhubungan lebih kuat dengan penurunan nilai rerata bahasa Indonesia dibandingkan dengan matematika. Sari Pediatri 2014;16(1):41-6.
\end{abstract}

Kata kunci: derajat obesitas, anak, prestasi belajar

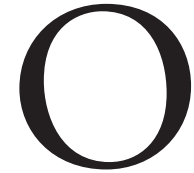

besitas merupakan keadaan patologis akibat konsumsi makanan yang melebihi kebutuhan sehingga terjadi penimbunan lemak yang berlebihan. ${ }^{1}$ Kejadian obesitas

\footnotetext{
Alamat korespondensi:

Dr. Kadek Hartini. Bagian/SMF Ilmu Kesehatan Anak FK-UNUD/ RSUP Sanglah, Jl. Pulau Nias Denpasar. Fakultas kedokteran Universitas Udayana. Telepon/Fax: (0361) 244038. E-mail: kadekhartini@ymail.com
}

meningkat di seluruh dunia, saat ini diperkirakan terdapat 300 juta penduduk yang menderita obesitas di seluruh dunia. ${ }^{2}$ Di Indonesia, data penelitian multisenter tahun 2004 yang dilakukan di sepuluh kota yaitu Medan, Padang, Palembang, Jakarta, Semarang, Solo, Jogjakarta, Surabaya, Denpasar dan Manado didapatkan prevalensi obesitas pada anak usia sekolah dasar sekitar $12 \% .^{3}$

Obesitas menimbulkan komplikasi penyakit kronis dan psikososial pada anak. ${ }^{4,5}$ Semakin berat 
derajat obesitas, komorbid yang dialami oleh anak obesitas juga semakin banyak. ${ }^{6}$ Obesitas juga menimbulkan stigma di masyarakat, dikatakan bahwa anak obesitas adalah anak yang malas, jelek, dan bodoh, ${ }^{7}$ walaupun sampai saat ini belum dapat dibuktikan adanya hubungan yang jelas antara prestasi belajar anak di sekolah dengan obesitas., ${ }^{5,7}$ Efek tidak langsung obesitas terhadap menurunnya fungsi kognitif diduga akibat dari dampak penyakit yang diderita oleh anak obesitas (diabetes, obstructive sleep apnea syndrome(OSAS), masalah respirasi), masalah psikososial (rendah diri, mengisolasi diri, dan depresi) ${ }^{4,8}$ dan kematangan sosial. ${ }^{9}$

Anak yang mengalami kesulitan belajar pada umumnya disertai kesulitan dalam berbahasa dan membaca. Lima puluh enam persen anak yang mengalami kesulitan dalam membaca, akan mengalami kesulitan juga dalam belajar matematika. ${ }^{10}$ Beberapa penelitian menunjukkan bahwa hubungan antara obesitas dengan prestasi belajar anak di sekolah masih kontradiktif, ${ }^{11}$ sedangkan hubungan antara derajat obesitas dengan prestasi belajar anak di sekolah belum pernah diteliti sebelumnya. Di Indonesia, mata pelajaran bahasa Indonesia dan matematika merupakan mata pelajaran wajib dalam kurikulum nasional siswa sekolah dasar. Atas dasar latar belakang tersebut maka penelitian dilakukan dengan tujuan mengetahui hubungan derajat obesitas pada siswa sekolah dasar dengan prestasi bahasa Indonesia dan matematika di sekolah.

\section{Metode}

Penelitian potong lintang analitik dilakukan di sekolah dasar (SD) swasta di wilayah kotamadya Denpasar dimulai dari Januari sampai dengan Juni 2011. Subyek dipilih secara acak bertingkat, tujuh SD swasta yang mempunyai kurikulum dan karakteristik yang hampir sama dipilih secara purposif random sampling. Di antara 2610 siswa, selanjutnya dipilih secara random sampling 1305 siswa sebagai subyek penelitian. Selanjutnya, dilakukan pemeriksaan antropometri untuk menentukan status nutrisi siswa. Pada kelompok siswa yang masuk dalam kriteria obesitas diikutsertakan sebagai subyek penelitian apabila memenuhi kriteria penerimaan dan tidak termasuk dalam kriteria penolakan. Besar sampel dihitung dengan rumus besar sampel untuk penelitian korelatif terhadap luaran yang akan dicari yaitu hubungan derajat obesitas dengan prestasi matematika dan bahasa Indonesia di sekolah, dengan $Z \alpha 1 \%$, Z $\beta$ 5\% dan koefisien korelasi minimal 0,4sehingga diperlukan 100 subyek.

Kriteria penerimaan adalah anak yang berusia 6-13 tahun, anak dengan obesitas (IMT $\geq \mathrm{P}_{95}$ ), anak bersedia untuk dilakukan pengukuran dan pemeriksaan, serta telah mendapat persetujuan dari orangtua (menandatangani persetujuan setelah mendapatkan penjelasan). Kriteria penolakan adalah anak yang tidak masuk sekolah saat pemeriksaan dilakukan. Pengukuran derajat obesitas dan pengisian kuesioner dilakukan pada setiap sampel yang memenuhi kriteria penerimaan. Tes intelegensi dilaksanakan oleh seorang psikolog dari konsultan psikologi Pradnyagama pada subjek yang memenuhi kriteria penerimaan, sedangkan nilai raport dan absensi dikumpulkan pada akhir semester 2.

Definisi operasional variabel adalah derajat obesitas berdasarkan atas BB/TB (\%) diklasifikasikan menjadi obesitas ringan (derajat I) $120-\leq 135 \%$, obesitas sedang (derajat II) $135-\leq 150 \%$, obesitas berat (derajat III) $150-\leq 200 \%$, dan super obesitas $>200 \%$. $^{12}$ Prestasi belajar dinilai dari pelajaran dalam raport adalah nilai bahasa Indonesia dan matematika. Mendengkur merupakan salah satu gejala dari OSAS ditanyakan dalam bentuk kuesioner pada pengasuh, asma ditegakkan bila sebelumnya anak pernah dikatakan menderita asma oleh dokter, persepsi diri dinilai dengan pertanyaan kuesioner "apakah anak merasa hubungan dengan teman terganggu, merasa malu dan jelek karena kegemukan?"

Analisis data dilakukan dalam beberapa tahap dengan memakai program komputer. Uji normalitas data dengan uji Kolmogorov-Smimov, selanjutnya dilakukan analisis regresi linier BB/TB (\%)terhadap nilai rerata matematika dan bahasa Indonesia. Dilakukan juga analisis korelasi bivariat faktor-faktor yang diperkirakan memiliki pengaruh pada prestasi mata pelajaran matematika dan prestasi mata pelajaran bahasa Indonesia.

\section{Hasil}

Telah dilakukan survei pada 1305 siswa SD, didapatkan $211(16,1 \%)$ anak dengan obesitas. Subyek yang mengikuti penelitian sampai selesai adalah 100 orang yang terdiri dari murid SD kelas I sampai VI. 
Rentang umur pada penelitian ini adalah 7 sampai 12 tahun (median 9 tahun), dengan skor IQ berada pada rentangan nilai 81 sampai 119 (median 98). Karakteristik dasar subyek penelitian tertera pada Tabel

Tabel 1. Karakteristik dasar subyek penelitian

\begin{tabular}{|c|c|}
\hline Variabel & $\mathrm{N}=100$ \\
\hline Umur (tahun), rentang (median) & $7-12(9)$ \\
\hline \multicolumn{2}{|l|}{ Jenis kelamin, $\mathrm{n}(\%)$} \\
\hline Laki-laki & 60 \\
\hline Perempuan & 40 \\
\hline \multicolumn{2}{|l|}{ Kelas,n (\%) } \\
\hline Kelas 1 & 17 \\
\hline Kelas 2 & 19 \\
\hline Kelas 3 & 14 \\
\hline Kelas 4 & 23 \\
\hline Kelas 5 & 19 \\
\hline Kelas 6 & 8 \\
\hline Skor IQ, rentang (median) & 81-119 (98) \\
\hline Berat badan (kg), rentang (median) & $25,00-83,00(44)$ \\
\hline Tinggi badan $(\mathrm{cm})$, rentang (median) & $110,0-157,0(134,9)$ \\
\hline \multicolumn{2}{|c|}{ Tingkat penghasilan orangtua, n (\%) } \\
\hline$<$ Rp. 2.500 .000 & 6 \\
\hline$\geq$ Rp. 2.500 .000 & 94 \\
\hline \multicolumn{2}{|l|}{ Tingkat pendidikan pengasuh, n (\%) } \\
\hline Tidak tamat SD & 1 \\
\hline Tamat SMP atau sederajat SMP & 1 \\
\hline Tamat SMA atau sederajat SMA & 33 \\
\hline Tamat perguruan tinggi & 65 \\
\hline \multicolumn{2}{|l|}{ Pekerjaan orangtua, n $(\%)$} \\
\hline Pegawai negeri sipil & 16 \\
\hline Pegawai swasta & 47 \\
\hline Wiraswasta & 36 \\
\hline Buruh & 1 \\
\hline \multicolumn{2}{|l|}{ Pengasuh, n (\%) } \\
\hline Ibu kandung & 93 \\
\hline Bukan ibu kandung & 7 \\
\hline \multicolumn{2}{|l|}{ Lama menonton TV, n (\%) } \\
\hline$<1$ jam & 8 \\
\hline $1-3$ jam & 77 \\
\hline$>3$ jam & 15 \\
\hline \multicolumn{2}{|l|}{ Fasilitas belajar, jam, n (\%) } \\
\hline Punya meja belajar & 91 \\
\hline Riwayat tinggal kelas & 4 \\
\hline \multicolumn{2}{|l|}{ Komorbid, n (\%) } \\
\hline Persepsi diri terganggu & 9 \\
\hline Terdiagnosis asma & 11 \\
\hline Mendengkur & 51 \\
\hline
\end{tabular}

1. Komorbid yang terbanyak adalah mendengkur. Ditemukan kecenderungan peningkatan proporsi komorbid dengan peningkatan derajat obesitas. Proporsi derajat obesitas dengan komorbid tertera pada Tabel 2.

Analisis regresi linier menunjukkan bahwa terdapat hubungan linier antara nilai rerata matematika dengan persentase derajat obesitas. Nilai R-square didapatkan 0,152 dengan persamaan regresi $y=98,106$ $0,154 x$ dengan nilai $p<0,001$. Penurunan nilai rerata matematika ditemukan 15\% berhubungan dengan peningkatan persentase derajat obesitas (Gambar 1).

Nilai rerata bahasa Indonesia dengan persentase derajat obesitas ditemukan terdapat hubungan pada analisis regresi linier yaitu penurunan nilai rerata bahasa Indonesia didapatkan $23 \%$ berhubungan dengan meningkatnya persentase derajat obesitas. Nilai R-square didapatkan sebesar 0,232 dengan persamaan regresi $y=105,634-0,195 x$ dengan nilai $\mathrm{p}=<0,001$ (Gambar 2).

Hasil analisis korelasi bivariat faktor-faktor yang diperkirakan memiliki pengaruh pada prestasi mata pelajaran matematika, diperoleh korelasi antara derajat obesitas dengan nilai matematika bermakna ( $<<0,001)$. Nilai korelasi Spearman -0,483 menunjukkan bahwa arah korelasi negatif dengan kekuatan korelasi sedang. Pada analisis korelasi bivariat faktor-faktor yang diperkirakan memiliki pengaruh pada prestasi mata pelajaran bahasa Indonesia, ditemukan terdapat korelasi antara derajat obesitas dengan nilai bahasa Indonesia dengan nilai signifikansi $\mathrm{p}<0,001$ dan nilai korelasi Spearman $-0,564$ yang menunjukkan bahwa arah korelasi negatif dengan kekuatan korelasi sedang.

\section{Pembahasan}

Pada penelitian ini didapatkan prevalensi obesitas $16,1 \%$, lebih besar 1,6 kali dibandingkan penelitian sebelumnya di Denpasar, pada prevalensi obesitas anak umur 8-12 tahun (9,7\%). ${ }^{13}$ Pada tahun 1995 , $\mathrm{Li}^{15}$ menemukan anak yang obesitas mempunyai nilai IQ yang lebih rendah dibandingkan anak normal terutama pada aspek berbahasa. Rendahnya IQ merupakan prediktor yang menyebabkan anak menjadi obesitas. ${ }^{14}$ Rentangan skor IQ didapatkan antara 81 sampai dengan 119 (median 98), menunjukkan subyek penelitian adalah obesitas primer dan untuk mengendalikan IQ sebagai faktor perancu. 
Tabel 2. Proporsi derajat obesitas dengan komorbid $(\mathrm{N}=100)$

\begin{tabular}{lccccccccccccc}
\hline $\begin{array}{l}\text { Derajat obesitas } \\
\text { n, (\%) }\end{array}$ & Jenis kelamin & \multicolumn{4}{c}{ Mendengkur } & \multicolumn{2}{c}{$\begin{array}{c}\text { Mulut terbuka } \\
\text { saat tidur }\end{array}$} & $\begin{array}{c}\text { Terdiagnosis } \\
\text { asma }\end{array}$ & $\begin{array}{c}\text { Riwayat } \\
\text { atopi pada } \\
\text { keluarga }\end{array}$ & $\begin{array}{c}\text { Persepsi diri } \\
\text { terganggu }\end{array}$ \\
\hline & Laki-laki & Perempuan & ya & tidak & ya & tidak & ya & tidak & ya & tidak & ya & tidak \\
\hline Ringan (n, \%) & $17(44)$ & 21 & $19(50)$ & 19 & $19(50)$ & 19 & $6(16)$ & 32 & $8(21)$ & 30 & $5(13)$ & 33 \\
Sedang (n, \%) & $24(70)$ & 10 & $17(50)$ & 17 & $19(55)$ & 15 & $3(8)$ & 31 & $4(11)$ & 30 & 0 & 34 \\
Berat (n, \%) & $16(64)$ & 9 & $13(52)$ & 12 & $16(64)$ & 9 & $1(4)$ & 24 & $4(16)$ & 21 & $4(19)$ & 21 \\
Super (n, \%) & $3(100)$ & 0 & $2(66)$ & 1 & $3(100)$ & 0 & $1(33)$ & 2 & 0 & 3 & 0 & 3 \\
\hline
\end{tabular}

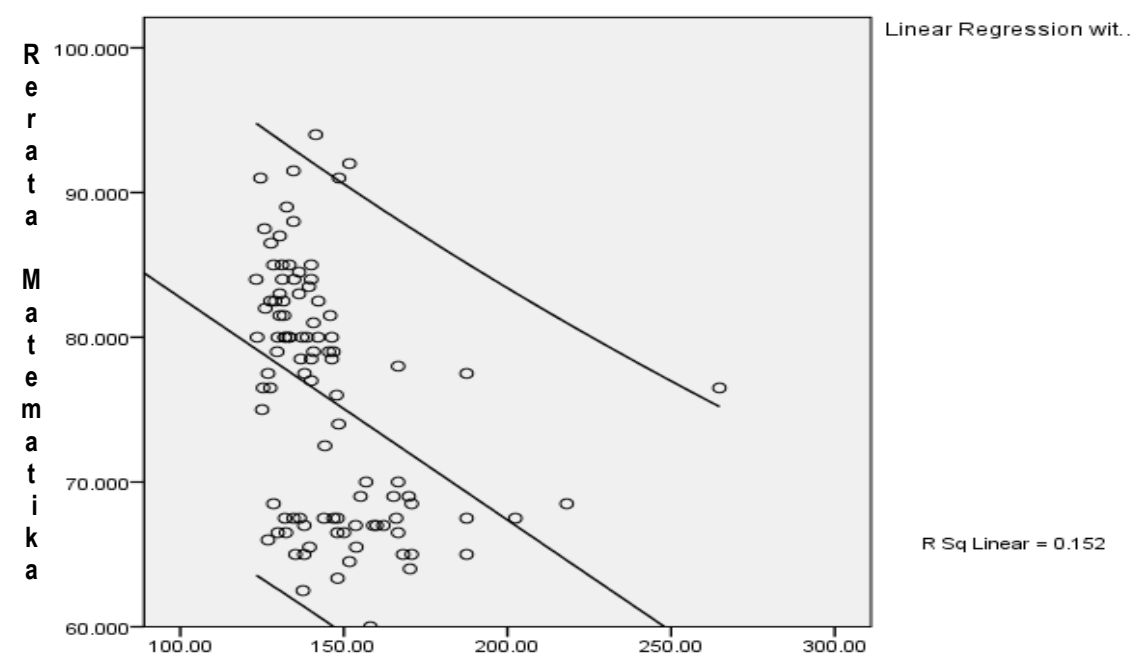

Gambar 1. Hubungan antara nilai rerata matematika dengan persentase derajat obesitas berdasarkan analisis regresi

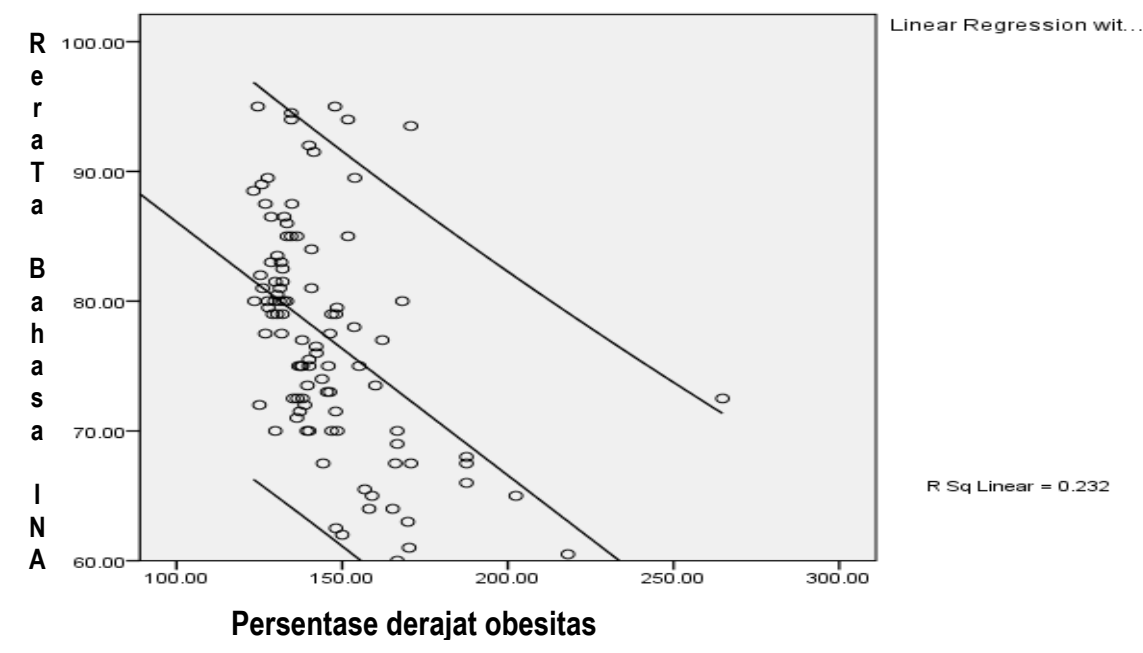

Gambar 2. Hubungan antara nilai rerata bahasa Indonesia dengan persentase derajat obesitas berdasarkan analisis regresi. 
Anak dengan obesitas derajat berat dikatakan lebih banyak absen di sekolah dibandingkan dengan anak yang tidak obesitas. ${ }^{16}$ Absensi berkaitan dengan komorbid dan ejekan yang dialami oleh anak obesitas. ${ }^{5,16} \mathrm{Hasil}$ analisis korelasi bivariat pada penelitian kami menemukan hasil yang berbeda, tidak terdapat hubungan antara jumlah absen dengan nilai matematika dan bahasa Indonesia.

Obesitas derajat ringan berkaitan dengan beberapa komorbid, sedangkan obesitas yang lebih berat yaitu super obesitas sangat erat kaitannya dengan munculnya berbagai macam komorbid. ${ }^{6}$ Komorbid terbanyak yang ditemukan adalah mendengkur, dan proporsi mendengkur cenderung meningkat dengan semakin meningkatnya derajat obesitas. Salah satu tanda dari OSAS adalah mendengkur, dikatakan anak yang menderita OSAS menjadi mengantuk, sulit berkonsentrasi sehingga kemampuan untuk mengikuti pelajaran dan aktivitas menjadi berkurang. ${ }^{17}$

Hasil yang berbeda didapatkan pada penelitian kami, yaitu tidak terdapat hubungan antara mendengkur dengan nilai matematika dan nilai bahasa Indonesia. Hal tersebut mungkin disebabkan oleh diagnosis OSAS hanya berdasarkan dugaan mendengkur yang diasumsikan sebagai OSAS.

Kejadian asma diduga berkaitan dengan obesitas pada anak, walaupun mekanismenya belum jelas, diduga alergi diperberat oleh meningkatnya respon inflamasi karena adanya obesitas. Anak yang obesitas disertai dengan asma akan mengurangi kemampuan anak untuk melakukan aktivitas olahraga dan aktivitas yang lain. ${ }^{18}$ Hasil yang didapat pada penelitian kami, proporsi subyek yang menderita asma $11 \%$, dengan kecenderungan proporsi yang semakin meningkat dengan semakin beratnya derajat obesitas.

Penelitian kami sudah melakukan analisis faktor yang kemungkinan berpengaruh pada prestasi belajar siswa sekolah dasar yang mengalami obesitas dengan kriteria eksklusi dan analisis korelasi, tetapi masih terdapat beberapa kelemahan pada penelitian kami. Asupan nutrisi dan aktivitas fisik yang merupakan faktor yang mungkin berpengaruh pada prestasi belajar anak di sekolah tidak kami analisis. Penelitian dengan desain kohort prospektif dibutuhkan untuk meningkatkan aplikasi penelitian ini pada populasi.

Sebagai penutup, disimpulkan bahwa terdapat peningkatan prevalensi anak dengan obesitas di Denpasar. Kecenderungan proporsi komorbid ditemukan meningkat sesuai dengan peningkatan derajat obesitas, dan derajat obesitas berhubungan bermakna dengan prestasi matematika dan bahasa Indonesia siswa sekolah dasar. Terdapat hubungan lebih kuat antara derajat obesitas dengan prestasi bahasa Indonesia dibandingkan dengan matematika.

\section{Daftar pustaka}

1. Suandi IKG. Obesitas pada remaja. Dalam: Soetjiningsih, penyunting. Tumbuh Kembang Remaja dan Permasalahannya. Edisi ke-1. Jakarta: Sagung Seto; 2004.h.77-88.

2. IOTF. The global challenge of obesity and the international obesity task force. IOTF Secretariat [serial online] 2009 [Diakses pada 5 Mei 2009]; [8 screen]. Didapat dari: URL: http://www.who.int/nut/obs.htm

3. Sjarif DR. Obesitas anak dan remaja. Dalam: Sjarif DR, Lestari ED, Mexitalia M, Nasar SS, penyunting. Buku Ajar Nutrisi Pediatrik dan Penyakit Metabolik. Edisi ke-1. Jakarta: BP IDAI; 2011. h. 230-41.

4. CDC. About childhood obesity. Division of nutrition, physical activity and obesity, national center for chronic disease prevention and health prevention and health promotion. Childhood Obesity Fact [serial online] 2009 [Diakses pada 1 April 2009];[11 screen]. Didapat dari: URL:http://www.cdc.gov/nccdphp/dnpa

5. Taras H, Datema WP. Obesity and student performance at school. J School Health 2005;19:421-40.

6. Kibbe DL. Opening presentations: advancing effective prevention and treatment. NIHCM Foundation action brief [serial online] 2003 [Diakses pada 3 Juni 2009]; [14 screen] Didapat dari: URL:http://www.nihcm.org

7. Wardle J. The impact of obesity on psychological well being. Best Practice \& Research Clin Endocrinol Metab 2005;19:421-40.

8. Wendt M, Kinsey J. Childhood overweight and school outcomes [thesis]. USDA: University of Minnesota; 2009.

9. Datar A, Sturm R, Magnobosco J. Chilhood overweight and academic performance: national study of kindergartners and first graders. Obes Res 2004;12:58-68.

10. Thaker VV. Learning disorder: mathematics. Jacobi. Department of Pediatrics Jacobi Medical Center; 2008.

11. Darmawan S, Purba M, Gamayanti LL. Harga diri, prestasi belajar dan pola makan pada remaja obesitas [thesis]. Yogyakarta: Program Studi Ilmu Kesehatan Masyarakat Sekolah Pascasarjana Universitas Gadjah Mada, 2007.

12. Soetjiningsih, Suandi IKG, Utama DL. Petunjuk 
pemeriksaan fisik pada bayi dan anak. Denpasar: Lab/ Ilmu Kesehatan Anak; 2000.

13. Dewi IA, Soetjiningsih, Patria Y. Hubungan obesitas dengan perkembangan seksual sekunder anak perempuan [thesis]. Yogyakarta: Ilmu Kedokteran Klinis Sekolah Pasca Sarjana Universitas Gadjah Mada; 2008.

14. Yu B, Han SP, Cao G, Guo XR. Intelligence in relation to obesity a systematic review and meta analysis. Obes Rev 2009;11:656-70.

15. Li X. A study of intelligence and personality in children with simple obesity. Int J Obes Relat Metab Disord 1995; 19:355-7.

16. Schwimmer JB, Burwinkle TM, Varni JW. Health related quality of live of severely obese children and adolescents. JAMA 2003;289:1813-9.

17. Barness LA, Opitz JM, Barness EG. Obesity: genetic, molecular and environmental aspects. Am J Med Gen 2007;143:3016-34.

18. Lee WR. An overview of pediatric obesity. Pediatric diabetes 2007;8:76-87. 